\title{
Decreased Aerobic Capacity in ANO5-Muscular Dystrophy
}

\author{
Ylikallio, Emil
}

2016-11-29

Ylikallio , E , Auranen , M , Mahjneh , I , Lamminen , A , Kousi , M , Träskelin , A-L , Muurinen, T , Löfberg , M , Salmi , T , Paetau , A , Lehesjoki , A-E , Piirilä , P \& Kiuru-Enari , S 2016 , ' Decreased Aerobic Capacity in ANO5-Muscular Dystrophy ', Journal of Neuromuscular Diseases , vol. 3 , no. 4 , pp. 475-485 . https://doi.org/10.3233/JND-160186

http://hdl.handle.net/10138/184157

https://doi.org/10.3233/JND-160186

acceptedVersion

Downloaded from Helda, University of Helsinki institutional repository.

This is an electronic reprint of the original article.

This reprint may differ from the original in pagination and typographic detail.

Please cite the original version. 
3 Emil Ylikallio ${ }^{\mathrm{a}, \mathrm{b}^{*},+}$, Mari Auranen ${ }^{\mathrm{a}, \mathrm{b},{ }^{*}}$, Ibrahim Mahjneh $^{\mathrm{c}, \mathrm{d}}$, Antti Lamminen $^{\mathrm{e}}$, Maria Kousi ${ }^{\mathrm{f}}$,

4 Ann-Liz Träskelin ${ }^{\mathrm{f}}$, Tiina Muurinen ${ }^{\mathrm{g}}$, Mervi Löfberg ${ }^{\mathrm{b}}$, Tapani Salmi ${ }^{\mathrm{h}}$, Anders Paetau ${ }^{\mathrm{i}}$,

5 Anna-Elina Lehesjoki ${ }^{\mathrm{a}, \mathrm{f}, \mathrm{j}}$, Päivi Piiriläg ${ }^{\mathrm{g}}$, Sari Kiuru-Enari ${ }^{\mathrm{b}}$

6

7 a Research Programs Unit, Molecular Neurology, Biomedicum Helsinki, University of

8 Helsinki, Helsinki, Finland

$9{ }^{\mathrm{b}}$ Clinical Neurosciences, Neurology, University of Helsinki and Helsinki University

10 Hospital, Finland

$11{ }^{c}$ Division of Neurology, Pietarsaari District Hospital, Pietarsaari, Finland

$12{ }^{\mathrm{d}}$ Department of Neurology, MRC Oulu, Oulu University Hospital and University of Oulu,

13 Finland

$14{ }^{\mathrm{e}}$ Department of Radiology, HUS Medical Imaging Center, Helsinki, Finland;

15 f Folkhälsan Institute of Genetics, Helsinki, Finland

$16 \mathrm{~g}$ Unit of Clinical Physiology, HUS Medical Imaging Center, Helsinki University Hospital,

17 Helsinki, Finland

$18{ }^{\mathrm{h}}$ Department of Clinical Neurophysiology, Medical Imaging Center, Helsinki University

19 Hospital, Helsinki, Finland

$20{ }^{\mathrm{I}}$ Department of Pathology, HUSLAB and University of Helsinki, Helsinki, Finland

$21{ }^{\mathrm{j}}$ Neuroscience Center, University of Helsinki, Finland

23 Running title: Exercise in ANO5 dystrophy 
$1+{ }^{+}$Correspondence to: Emil Ylikallio, Biomedicum r.C526b, Haartmaninkatu 8, 00290

2 Helsinki, Finland. E-mail: emil.ylikallio@ @elsinki.fi, Telephone: +358-50-448-6380, fax:

$3+358-91-912-5610 . *$ Equal contribution.

4

5

6

7

8

9

10

11

12

13

14

15

16

17

18

19

20

21

22

23 


\section{ABSTRACT}

2 BACKGROUND: Anoctaminopathies are muscle diseases caused by recessive mutations

3 in the ANO5 gene. The effects of anoctaminopathy on oxidative capacity have not

4 previously been studied in a controlled setting.

5 OBJECTIVE: To characterize oxidative capacity in a clinically and genetically well-

6 defined series of patients with anoctaminopathy.

7 METHODS: We sequenced the ANO5 gene in 111 Finnish patients with suspected

8 LGMD2. Patients with positive findings underwent close clinical examination, including

9 electromyography, muscle MRI, and, in selected cases, muscle biopsy. Oxidative capacity

10 was analyzed using spiroergometry and compared to age-matched healthy controls.

11 RESULTS: We characterized 12 newly identified and 2 previously identified patients with

12 ANO5 mutations from 11 families. Our material was genetically homogeneous with most

13 patients homozygous for the Finnish founder variant c.2272C>T (p.Arg758Cys). In one

14 family, we found a novel p.Met470Arg variant compound heterozygous with p.Arg758Cys.

15 Lower limb muscle MRI revealed progressive fatty degeneration of specific posterior

16 compartment muscles. Patients' spiroergometric profiles showed that anoctaminopathy

17 significantly impaired oxidative capacity with increasing ventilation.

18 CONCLUSIONS: Our findings support earlier reports that anoctaminopathy progresses

19 slowly and demonstrate that the disease impairs the capacity for aerobic exercise. 


\section{KEYWORDS}

2 Muscular dystrophies, limb-girdle; Muscular Diseases; Inborn Genetic Diseases; Aerobic

3 Exercise

4

\section{ABBREVIATIONS}

6 AT

$7 \quad \mathrm{BE}$

8 CK

9 EMG

10 ExAC

$11 \quad$ FetCO2

$12 \quad$ FVC

13 LGMD

14 MMD3

15 RPE

16 RQ

17 SE

18 TI

19 VECO2

$20 \quad \mathrm{VEO} 2$

$21 \quad V^{\prime} \mathrm{O} 2 \mathrm{max}$

$22 \mathrm{Wmax} / 3 \min$

$23 \mathrm{Wmax} / \mathrm{V}^{\prime} \mathrm{O} 2 \max$ anaerobic threshold

base excess

creatine kinase

electromyography

Exome Aggregation Consortium

fraction of end tidal $\mathrm{CO} 2$

forced vital capacity

limb-girdle muscular dystrophy

Miyoshi myopathy

rate of perceived exertion

gas exchange ratio $\mathrm{V}^{\prime} \mathrm{CO} 2 / \mathrm{V}^{\prime} \mathrm{O} 2$

spin echo

inversion time

ventilatory equivalent for $\mathrm{CO} 2$ production

ventilatory equivalent for $\mathrm{O} 2$ uptake

maximal oxygen uptake

mean workload during the last 3 minutes of exercise

mechanical efficiency 


\section{INTRODUCTION}

2 Anoctaminopathies are muscle diseases caused by recessively inherited ANO5 mutations

3 first identified in proximal limb-girdle muscular dystrophy type 2L (LGMD2L) and distal

4 non-dysferlin Miyoshi myopathy (MMD3) [1, 2]. The phenotypic heterogeneity of

5 anoctaminopathy has since expanded, with the mildest cases presenting as the

6 asymptomatic elevation of creatine kinase ('hyperCK-emia') [1, 3]. The symptoms and

7 signs are restricted to skeletal muscle in most cases, but occasionally patients present with

8 a suspicion of heart involvement [4, 5]. Using muscle MRI, we and others have shown that

9 anoctaminopathy typically involves the posterior compartments of the thighs and calves

10 rather than the anterior compartments [6-8].

12 Vissing et al recently reported positive effects from a 10-week supervised aerobic exercise

13 regimen in patients with anoctaminopathy [9]. However, little controlled data exist

14 measuring the effects of the disease on baseline oxidative capacity. Spiroergometric testing

15 (breathing gas analysis during exercise) with the simultaneous analysis of blood lactate and

16 ammonia concentrations provides not only an objective means of evaluating pulmonary,

17 skeletal, and heart muscle involvement, but can also underline biochemical abnormalities

18 through the monitoring of blood metabolites [10].

20 This study aimed to characterize a series of anoctaminopathy patients specifically

21 emphasizing oxidative performance, an aspect that has been little studied previously.

22 Patients were examined in detail, including by muscle MRI, changes in muscle pathology,

23 and spiroergometric testing. 


\section{MATERIALS AND METHODS}

\section{Patients}

3 Patients were examined at Helsinki University Hospital. All patients and healthy controls

4 subjects provided their informed consent to participate in the study, and investigations were

5 conducted in accordance with the 1975 Declaration of Helsinki. Furthermore, the ethics

6 committee of the Hospital District of Helsinki and Uusimaa approved the study protocol.

7 Total DNA was extracted from peripheral blood, and the coding exons and flanking intron

8 sequences of the ANO5 gene (NM_213599.2) were sequenced. Primer sequences are

9 available upon request from the authors. Variants whose pathogenicity were previously

10 unknown were scored using PolyPhen-2 v.2.2.5 (http://genetics.bwh.harvard.edu/pph2/)

11 [11] and Mutation Taster 2 (http://www.mutationtaster.org/) [12]. The population

12 frequencies for variants were taken from the Exome Aggregation Consortium (ExAC,

13 http://exac.broadinstitute.org/, accessed August 2015). Novel variants were submitted to

14 the ClinVar database (http://www.ncbi.nlm.nih.gov/clinvar/).

16 Spiroergometry, control subjects, laboratory specimens, and statistical methods

17 Spiroergometric exercise testing was completed for 12 ANO5 variant-positive patients and

1824 age- and gender-adjusted controls using follow-up venous lactate and ammonium 19 samples (Table 1).

21 Spiroergometry was performed as described earlier [13]. A cannula was inserted into the

22 left cubital vein, and the blood specimens for venous ammonia and lactate were drawn at

23 nine time points: at rest, low exercise, maximal exercise, and at 2, 4, 6, 10, 20, and $30 \mathrm{~min}$ 
1 after exercise. Blood specimens were collected using the vacuum technique. Following a

2 waste specimen of $2 \mathrm{ml}$, the lactate and ammonia specimens were placed into fluoride

3 oxalate and EDTA syringes, respectively, centrifuged, and analyzed with a Cobas Integra

4 400+ analyzer (Roche Diagnostics, Mannheim, Germany). Lactate and ammonia were

5 assayed by enzymatic methods using lactate dehydrogenase and glutamate dehydrogenase,

6 respectively. Next, 3-ml samples for the analysis of the venous blood gases were placed in

7 Ca-titrated Lithium heparin syringes and analyzed using a Radiometer ABL800 analyzer

8 (Radiometer Medical, Bronshoj, Danmark). The test started with a 40-W workload

9 increased by $40 \mathrm{~W}$ in 3-min steps in women and increased by $50 \mathrm{~W}$ in 3-min steps in men.

10 If the patient's reported physical condition was low, we used 20-W increases in 2-min steps

11 or $30 \mathrm{~W}$ in 3-min steps. We attained a rate of perceived exertion (RPE) of 17 to 19 on the

12 Borg scale and a gas exchange ratio $\mathrm{V}^{\prime} \mathrm{CO}_{2} / \mathrm{V}^{\prime} \mathrm{O}_{2}(\mathrm{RQ})$ of more than 1.0 for all participants.

14 We used an unpaired t-test to analyze the spiroergometric results as well as the results of

15 the venous blood specimen between patients and controls; a nonparametric Mann-Whitney

$16 \mathrm{U}$ test was used for parameters not normally distributed. Because of the multiple

17 comparisons, we used a Bonferroni correction to the significance level applied. Due to the

18 slight difference in the weight and BMI between the groups, we controlled the results of

19 the spiroergometric variables for BMI.

21 The patient and control groups had slight differences in maximal level of exercise in the

22 spiroergometric test. To control for this difference in the comparison of spiroergometric

23 data, we normalized the data according to blood lactate levels. This is because the lactate 
1 level increases with the level of anaerobic metabolism and is therefore a measure of the

2 level of exercise during the test.

4 Increase of lactate increases ventilation, which can be measured as increase of ventilatory

5 equivalent for $\mathrm{O} 2$ and $\mathrm{CO} 2(\mathrm{VE} / \mathrm{O} 2 \%$ and $\mathrm{VE} / \mathrm{CO} 2)$ and decrease of fraction of end tidal

$6 \mathrm{CO} 2(\mathrm{FetCO} 2 \%)$. In the patients, $\mathrm{VE} / \mathrm{O} 2 \%$ and $\mathrm{VE} / \mathrm{CO} 2 \%$ were increased and $\mathrm{FetCO} 2 \%$

7 decreased. This could have been interpreted as increased anaerobic metabolism, suggesting

8 patients' exercise tests to be more maximal than those of the controls. By controlling

9 spiroergometric variables for maximal lactate levels in addition to BMI, we could see that

10 the level of exercise of the patients was not greater than in the controls. Before these

11 calculations, we had analyzed the behavior of lactate and ammonia associated with exercise,

12 and no specific findings were seen. The respiratory quotient, RQ, could also have been

13 used to control for the level of exercise. However, maximal lactate level serves here better

14 as adjustment because, in contrast to RQ, lactate is not a spiroergometric variable itself.

\section{Muscle MRI}

17 MRI was performed using a $1.5 \mathrm{~T}$ Siemens system. Axial images were acquired for the

18 pelvic, thigh, and leg muscles. The pulse sequences were T1-weighted spin echo (SE) with

19 TR of 600 to $700 \mathrm{~ms}$, TE of $15 \mathrm{~ms}$, and a STIR fat suppression sequence with TR of 3200

20 to $4300 \mathrm{~ms}$, TE of $33 \mathrm{~ms}$, and an inversion time (TI) of $160 \mathrm{~ms}$. Slices of $7 \mathrm{~mm}$ were used.

21 The involvement of each muscle was scored on a scale of 0 to 3 , where 0 indicated normal,

221 indicated minor involvement, 2 indicated moderate involvement, and 3 indicated

23 maximal involvement. Aggregate scores were computed for the muscles of the thigh 
1 (quadriceps femoris, adductors, hamstrings, sartorius, and gracilis) and lower leg (tibialis

2 posterior, peroneus, deep posterior compartment, soleus, and gastrocnemius). Based on

3 five leg and thigh muscles, the maximum aggregated score was 15. Follow-up scans were

4 performed using the same scanner and identical parameters for patients 1 (2 years between

5 scans), 2 (4 years between scans), 4 ( 2 years between scans), 7 ( 2 years between scans), 9

6 ( 2 years between scans), and 13 (12 years between scans).

\section{RESULTS}

\section{Screening of the ANO5 gene}

10 We sequenced the ANO5 coding regions and flanking intron sequences in 111 patients with

11 suspected myopathy of an undetermined cause based on symptoms and clinical findings,

12 an elevated CK, myopathic electromyography (EMG), muscle biopsy, or muscle MRI. We

13 identified 12 patients from 10 families as positive for ANO5 variants (Table 2). Clinical

14 and genetic data from patients 13 and 14 were previously reported $[1,2,8]$.

16 The most common genetic finding was homozygous ANO5 c.2272C $>\mathrm{T}$ (p.Arg758Cys).

17 Eight patients were homozygous for this variant, while the remaining four were compound

18 heterozygous for p.Arg758Cys in combination with either c.191dupA (p.Asn62LysfsX15),

19 c.1409T $>\mathrm{G}$ (p.Met470Arg), or c.1664G $>\mathrm{T}$ (p.Ser555Ile) (Table 2). The latter two variants

20 have not previously been confirmed as pathogenic in anoctaminopathy. Both were

21 predicted as 'disease causing' by Mutation Taster, whereas PolyPhen-2 rated p.Met470Arg

22 as 'possibly damaging' and p.Ser555Ile as 'probably damaging'. The population frequency 
1 of p.Ser555Ile was $1.2 \times 10^{-4}$ in European populations, whereas p.Met470Arg was not found

2 in the ExAC database.

4 Clinical, neurophysiologic, and pathologic findings

5 Despite being relatively genetically homogeneous, our anoctaminopathy series showed

6 some variability in clinical features (Table 2). Six of our 14 patients were female. The age

7 of reported symptom onset ranged from 12 to 62 years, with an average age of 33 for female

8 patients (SD 5.9 years) and 31 for male patients (SD 16 years). The disease duration ranged

9 from 6 to 58 years. At onset, three patients complained of muscle pain, unpleasant muscle

10 sensations in the calves, and cramps. Six patients initially experienced difficulty walking

11 on their tiptoes, two patients complained of difficulty climbing stairs, and two patients

12 complained of difficulty running and climbing stairs. One patient reported no muscle

13 symptoms and an increased CK was found incidentally. During the course of the disease,

14 muscle pain, stiffness, or cramps were common among all patients. Clinical examination

15 showed distal lower limb muscle involvement in six patients, proximal involvement in two

16 patients, and both distal and proximal involvement in six patients.

17 Plasma CK ranged from 240 to 12,290 IU/l. EMG findings were myopathic in 7 out of 12

18 patients tested. Four patients exhibited both neurogenic and myopathic features, whereas

19 one patient had a normal EMG (Table 2). Muscle biopsies were obtained from 13 patients.

20 The findings ranged from necrotizing myopathy or strong dystrophic changes to mild

21 atrophy of type 2 fibers. Three out of nine patients who underwent cardiac ultrasound had

22 slightly abnormal findings primarily attributed to hypertension (Table 2). ECGs showed

23 normal findings for all patients (Table 4). 


\section{$1 \quad$ Skeletal muscle imaging}

2 Table 3 summarizes the muscle MRI findings. Muscle T1-weighted MRI scans showed

3 fatty replacement predominantly in the adductors, hamstrings, gastrocnemius, and soleus.

4 Muscle MRI STIR-weighted scans showed hyperintensities suggesting myoedema

5 primarily in the hamstrings, quadriceps, adductors, gastrocnemius, and soleus. These

6 findings were more evident at the early stages of disease.

8 In six patients who completed two follow-up MRI scans, the total T1 score increased by

9 an average of 0.6 (SD 0.7) points per year in the thighs and 0.6 (SD 0.3) points per year in

10 the legs based on the 0 to 15 scoring scale. The STIR score does not show any significant

11 change over time. Thus, the progression of the disease is reflected in any sequential

12 increases in fatty degeneration observable in T1 imaging. Representative images from one 13 patient are shown in Figures $1 \mathrm{~A}-\mathrm{F}$.

\section{Spiroergometric testing}

16 Table 1 shows the anthropometric and spirometric characteristics for patients and controls.

17 During the exercise test, patients with anoctaminopathy exhibited a significantly lower 18 maximal working capacity (Wmax/3min), maximum oxygen uptake (VO2max), oxygen

19 pulse (V'O2/HR), and mechanical efficiency (Wmax/V'O2max) than those for controls

20 (Table 4). However, the respiratory quotient $\left(\mathrm{V}^{\prime} \mathrm{CO}_{2} / \mathrm{V}^{\prime} \mathrm{O}_{2}\right)$ tended to be higher in patients,

21 and signs of increased ventilation demonstrated by a significantly increased ventilatory

22 equivalent for $\mathrm{O}_{2}\left(\mathrm{VE} / \mathrm{V}^{\prime} \mathrm{O}_{2}\right)$ and $\mathrm{CO}_{2}\left(\mathrm{VE} / \mathrm{V}^{\prime} \mathrm{CO}_{2}\right)$ in addition to a decreased fraction of 23 end-tidal $\mathrm{CO}_{2}\left(\mathrm{FetCO}_{2}\right)$ were seen in patients compared to controls. 
1 In the blood gas analyses, patients exhibited the lowest blood $\mathrm{pH}$ of 7.3 at 2 to 6 min and

2 the lowest base excess $(\mathrm{BE})-5.5 \mathrm{mmol} / \mathrm{l}$ at $6 \mathrm{~min}$ after exercise, while the corresponding

3 values in controls were $\mathrm{pH}$ of 7.26 at $2 \mathrm{~min}$ and $\mathrm{BE}-7.77 \mathrm{mmol} / \mathrm{l}$ at $4 \mathrm{~min}$ after exercise.

4 For the BE values, we found a significant difference between patients and controls at 2 and

54 min after exercise ( $p=0.039$ and 0.013 , respectively), and a significant difference in the

$6 \mathrm{pH}$ values at $2 \mathrm{~min}$ after exercise $(\mathrm{p}=0.048)$. In addition, we found significantly lower

7 lactate readings in patients compared to controls $(p=0.049)$ at 2 and 4 min after exercise.

8 However, we found no difference between patients and controls in the levels of ammonia

9 (Figure 2).

\section{DISCUSSION}

12 We studied a cohort of patients with ANO5-related dystrophy, providing a detailed clinical

13 analysis. Anoctaminopathy has been reported in several countries, including Canada [2],

14 the UK and Germany [6, 14], Finland [1, 3], the Netherlands [2, 15], Denmark [5], the

15 Czech Republic [16], and Italy and other countries in Europe and worldwide [17-19]. We

16 found that $11 \%$ of our suspected LGMD patients had ANO5 mutations, supporting that they

17 are a common cause of myopathy in northern Europe.

19 We found the variant c.2272C>T (p.Arg758Cys) in all of our patients, appearing as

20 homozygous in 10 patients from 8 families and as compound heterozygous with another

21 variant in 4 patients from 3 families. This finding is not surprising since c. $2272 \mathrm{C}>\mathrm{T}$ has a

22 carrier frequency of $0.35 \%$ in Finland, thus explaining most known Finnish cases [3].

23 Among the compound heterozygous patients, one had the c.191dupA (p.Asn62Lysfs15X) 
1 variant, which is common in other Northern European populations [14]. One patient had

2 the c.1664G $>\mathrm{T}$ (p.Ser555Ile) variant, which was recently found in the heterozygous state

3 in a patient sequenced as part of a cohort of patients with LGMD or unspecified myopathy

4 [17]. Bioinformatic predictions support the pathogenicity of this variant. However, since

5 carriers are found in European populations, it is likely that a second hit is necessary on the

6 other allele for this variant to cause disease, as was the case in our patient. Finally, two

7 siblings (Family J, patients 11 and 12) presented with previously unknown variant

8 c.1409T $>$ G (p.Met470Arg). This variant received high scores for pathogenicity using

9 bioinformatics tools, and was not found in public exome databases.

11 The clinical findings in our anoctaminopathy patients correspond to previous descriptions,

12 featuring asymmetric proximal or distal muscle involvement and myalgia $[1-3,5,6,14-$

13 20]. We found a tendency towards asymmetric muscle involvement, a feature of

14 anoctaminopathy not typically reported for other forms of LGMD $[2,21]$ with the

15 exception of facioscapulohumeral muscle dystrophy. Echocardiographic abnormalities

16 were documented in only three patients, all associated with hypertension.

18 Our findings provide further confirmation of the variable age of onset of anoctaminopathy.

19 Even in the presence of the homozygous p.Arg758Cys variant, initial symptoms were

20 reported between the ages of 12 and 62 years. The variable age of onset suggests the

21 presence of genetic or environmental disease modifiers. Previous reports have well-

22 documented an association between being male and anoctaminopathy [3, 14, 15, 22]. 
1 However, we found no significant difference in the average age of disease onset based on

2 gender, although the variance for the age of onset was greater among the men in our study.

4 Earlier radiologic studies by us and others demonstrated that anoctaminopathy affects

5 lower leg muscles, suggesting predominantly posterior compartment involvement in both

6 the thighs and the legs. The tibialis anterior, gracilis, and sartorius are better spared, similar

7 to other LGMDs, indicating that MRI may not be the best diagnostic tool [1, 6-8]. The

8 results presented here further demonstrate that fatty degeneration tends to increase as the

9 disease progresses. Therefore, T1-weighted MRI may be useful as a follow-up tool or as

10 an assessment tool for potential treatment. The STIR technique is a sensitive tool in early

11 diagnostics, but not in the later stages of disease. Furthermore, EMG results remain

12 variable, featuring both myopathic and neurogenic findings.

14 To our knowledge, this is the first study to explore the oxidative capacity of 15 anoctaminopathy patients compared to an anthropometrically matched control population.

16 Patients with anoctaminopathy showed significantly lower oxygen uptake than controls,

17 which may serve as a primary feature of the disease or secondary to deconditioning

18 provoked by muscle weakness and pains. Additionally, the patients' oxygen pulse

19 (V'O2/HR) was lower than controls, most likely associated with the diminished capacity

20 of the peripheral muscles $[23,24]$. The level of maximal oxygen uptake reported here

21 corresponds to that measured by Vissing et al [9] before regular aerobic training. 
1 In patients, we found an excess of ventilation accompanied an increase in the ventilatory

2 equivalents for $\mathrm{O}_{2}$ and $\mathrm{CO}_{2}$. In addition, more than half (7/12 patients) had $\mathrm{FetCO}_{2}$ lower

3 than $4.5 \%$ during maximal exercise suggesting slight hyperventilation. By contrast,

4 controls showed normoventilation, although we expected them to display a stronger

5 respiratory compensation due to stronger metabolic acidosis associated with exercise

6 compared to patients. The spirometric findings did not explain this inconsistency. The

7 forced vital capacity (FVC) was slightly lower in patients than in healthy controls, but only

8 one patient (patient 9) developed restrictive ventilatory impairment (FVC $<80 \%$ of the

9 predicted value), suggesting that ventilatory function was not the cause of the increased

10 ventilation. The increased ventilation might be explained by the lowered aerobic exercise

11 capacity of the muscles leading to secondary hyperventilation during exercise. In addition,

12 the reduced mechanical efficiency ( $\mathrm{Wmax} / \mathrm{V}^{\prime} \mathrm{O}_{2} \max$ ) most likely reflected this finding,

13 indicating an increased need for oxygen uptake related to the attained workload.

15 Patients' lactate and ammonia levels tended to be lower than those among controls. This

16 might be explained by the lower exercise capacity due to muscle disease. However, the RQ

17 levels of patients tended to be higher than those among controls indicating at least the same

18 level of aerobic capacity among both patients and healthy controls. We should note that an

19 increase in ventilation may partly explain the elevated RQ levels we observed in patients.

20 We found no specific findings or indications of metabolic muscular myopathy.

22 In conclusion, our report confirms the importance of the recessive ANO5 variants as causes

23 of muscle disease with significant variability in clinical severity. In addition, we found a 
1 new disease-associated variant, and provide an initial and detailed case-control

2 comparison suggesting a decreased oxidative capacity. Our results support aerobic training

3 as a useful intervention to mitigate the symptoms of anoctaminopathy. Further studies

4 featuring a larger sample of patients are needed to confirm our findings.

6 ACKNOWLEDGEMENTS

7 We thank all individuals who participated in this study. The authors wish to thank the

8 following for their financial support of this research: Hospital District of Helsinki and

9 Uusimaa (for S.K-E., M.A., and E.Y.), the Academy of Finland (for E.Y.), and the

10 Folkhälsan Research Foundation (for A.-E.L.).

\section{CONFLICTS OF INTEREST}

13 The authors have no conflicts of interest to report. 


\begin{tabular}{|lll|}
\hline & $\begin{array}{l}\text { Patients with an ANO5 } \\
\text { deficiency } \\
(N=12)\end{array}$ & $\begin{array}{l}\text { Healthy controls } \\
(N=24)\end{array}$ \\
\hline Sex $(\mathrm{m} / \mathrm{f})$ & $6 / 6$ & $12 / 12$ \\
\hline Weight $(\mathrm{kg})$ & $81.7(18.8)$ & $75.1(14.8)$ \\
\hline Height $(\mathrm{cm})$ & $169.8(10.9)$ & $165.3(36.4)$ \\
\hline BMI & $28.2(5.4)$ & $23.9(5.8)$ \\
\hline Age & $50.6(10.5)$ & $45.7(10.6)$ \\
\hline FVC $(\mathrm{l})$ & $4.05(0.87)$ & $4.6(1.3)$ \\
\hline FVC \% of pred. & $94.3(10.4)$ & $102.5(12.3)$ \\
\hline FEV1 $(\mathrm{l})$ & $3.33(0.73)$ & $3.63(0.21)$ \\
\hline FEV1 \% of pred. & $95.2(11.6)$ & $98.9(11.4)$ \\
\hline
\end{tabular}

2 Table 1. Anthropometric characteristics of patients and controls. $\mathrm{FVC}=$ forced vital

3 capacity, FEV1 = forced expiratory volume in $1 \mathrm{~s}$, pred. = predicted value. Means and

4 standard deviations (in parenthesis) are presented.

5

6

7

8

10

11

12

13 


\begin{tabular}{|c|c|c|c|c|c|c|c|c|c|c|c|c|}
\hline $\begin{array}{l}\text { Patient } \\
\text { (family) }\end{array}$ & Sex & $\begin{array}{l}\text { Age at } \\
\text { onset }\end{array}$ & $\begin{array}{l}\text { Current } \\
\text { age }\end{array}$ & $\begin{array}{l}\mathrm{CK}, \mathrm{IU} / \mathrm{l}, \\
\text { range }\end{array}$ & $\begin{array}{l}\text { ECG and } \\
\text { cardiac US }\end{array}$ & $\begin{array}{l}\text { Spiro- } \\
\text { ergo- } \\
\text { metry }\end{array}$ & Clinical phenotype & $\begin{array}{l}\text { MRI } \\
\text { thighs }\end{array}$ & $\begin{array}{l}\text { MRI } \\
\text { legs }\end{array}$ & Biopsy & EMG & $\begin{array}{l}\text { ANO5 } \\
\text { genotype }\end{array}$ \\
\hline $1(\mathrm{~A})$ & $\mathrm{M}$ & 17 & 65 & $\begin{array}{l}1,337- \\
3,279\end{array}$ & Normal & + & $\begin{array}{l}\text { Distal weakness of } \\
\text { right UL, later LL } \\
\text { fatigue, myalgia, } \\
\text { cramps }\end{array}$ & 5 & 3 & $\begin{array}{l}\text { Chronic necrotizing } \\
\text { myopathy with } \\
\text { dystrophic features }\end{array}$ & Myopathic & $\begin{array}{l}\text { p.R758C } \\
+ \\
\text { p.R758C }\end{array}$ \\
\hline $2(\mathrm{~A})$ & M & 62 & 68 & $650-4,542$ & $\begin{array}{l}\text { Mildly } \\
\text { hypertrophic } \\
\text { left ventricle }\end{array}$ & + & $\begin{array}{l}\text { Mild distal LL } \\
\text { weakness }\end{array}$ & 6 & 3 & $\begin{array}{l}\text { Chronic necrotizing } \\
\text { myopathy with } \\
\text { dystrophic features }\end{array}$ & Myopathic & $\begin{array}{l}\text { p.R758C } \\
+ \\
\text { p.R758C }\end{array}$ \\
\hline $3(\mathrm{~B})$ & $\mathrm{F}$ & 31 & 43 & $272-2,023$ & Normal & + & $\begin{array}{l}\text { LL myalgia, cramps } \\
\text { and weakness }\end{array}$ & 0 & 2 & $\begin{array}{l}\text { No diagnostic } \\
\text { changes, mild fiber } \\
\text { type } 2 \text { atrophy }\end{array}$ & Myopathic & $\begin{array}{l}\text { p.R758C } \\
+ \\
\text { p.R758C }\end{array}$ \\
\hline $4(\mathrm{C})$ & $\mathrm{M}$ & 12 & 52 & $\begin{array}{l}1,027- \\
60,000\end{array}$ & $\begin{array}{l}\text { Mild } \\
\text { diastolic } \\
\text { relaxation } \\
\text { abnormality }\end{array}$ & + & $\begin{array}{l}\text { Distal LL cramps, } \\
\text { exercise intolerance, } \\
\text { later UL weakness }\end{array}$ & 3 & 4 & Nonspecific myopathy & Myopathic & $\begin{array}{l}\text { p.R758C } \\
+ \\
\text { p.R758C }\end{array}$ \\
\hline $5(\mathrm{D})$ & $\mathrm{F}$ & 34 & 53 & $\begin{array}{l}1,367- \\
3,363\end{array}$ & Normal & + & $\begin{array}{l}\text { Distal LL weakness, } \\
\text { stiffness, myalgia, UL } \\
\text { weakness (marginal) }\end{array}$ & 6 & 6 & $\begin{array}{l}\text { No diagnostic } \\
\text { changes, mild fiber } \\
\text { type } 2 \text { atrophy }\end{array}$ & Myopathic & $\begin{array}{l}\text { p.R758C } \\
+ \\
\text { p.R758C }\end{array}$ \\
\hline $6(\mathrm{E})$ & M & 40 & 60 & $766-2,517$ & $\begin{array}{l}\text { ECG } \\
\text { normal, US } \\
\text { ND }\end{array}$ & - & $\begin{array}{l}\text { Progressive proximal } \\
\text { LL weakness, later } \\
\text { proximal right UL } \\
\text { weakness }\end{array}$ & 9 & 6 & $\begin{array}{l}\text { Dystrophic and } \\
\text { secondary } \\
\text { inflammatory changes }\end{array}$ & $\begin{array}{l}\text { Myopathic, } \\
\text { LL } \\
\text { neuropathy }\end{array}$ & $\begin{array}{l}\text { p.R758C } \\
+ \\
\text { p.N62Kfs } \\
15 \mathrm{X}\end{array}$ \\
\hline $7(\mathrm{~F})$ & $\mathrm{F}$ & 38 & 51 & $921-5,119$ & $\begin{array}{l}\text { Slight apical } \\
\text { septal } \\
\text { thickening }\end{array}$ & + & $\begin{array}{l}\text { Restless legs, CK } \\
\text { elevation, later LL } \\
\text { myalgia }\end{array}$ & 0 & 3 & $\begin{array}{l}\text { Mild chronic } \\
\text { myopathy }\end{array}$ & Myopathic & $\begin{array}{l}\text { p.R758C } \\
+ \\
\text { p.R758C }\end{array}$ \\
\hline $8(\mathrm{G})$ & $\mathrm{M}$ & 38 & 69 & 1,300 & Normal & + & $\begin{array}{l}\text { Proximal LL and UL } \\
\text { weakness, myalgia }\end{array}$ & 14 & 3 & Dystrophic features & Myopathic & $\begin{array}{l}\text { p.R758C } \\
+ \\
\text { p.R758C }\end{array}$ \\
\hline $9(\mathrm{H})$ & $\mathrm{F}$ & 29 & 56 & $\begin{array}{l}2,000- \\
3,000\end{array}$ & $\begin{array}{l}\text { ECG } \\
\text { normal, US } \\
\text { ND }\end{array}$ & + & $\begin{array}{l}\text { LL myalgia and mild } \\
\text { weakness }\end{array}$ & 6 & 3 & $\begin{array}{l}\text { Mild necrotizing } \\
\text { myopathy with } \\
\text { dystrophic features }\end{array}$ & $\begin{array}{l}\text { Myopathic } \\
\text { and } \\
\text { neurogenic } \\
\text { features }\end{array}$ & $\begin{array}{l}\text { p.R758C } \\
+ \\
\text { p.R758C }\end{array}$ \\
\hline $10(\mathrm{I})$ & $\mathrm{F}$ & 25 & 31 & $240-2,973$ & Normal & + & LL myalgia, fatigue & 0 & 0 & Myopathic changes & Normal & $\begin{array}{l}\text { p.R758C } \\
+ \\
\text { p.S555I }\end{array}$ \\
\hline
\end{tabular}




\begin{tabular}{|c|c|c|c|c|c|c|c|c|c|c|c|c|}
\hline $\begin{array}{l}\text { Patient } \\
\text { (family) }\end{array}$ & Sex & $\begin{array}{l}\text { Age at } \\
\text { onset }\end{array}$ & $\begin{array}{l}\text { Current } \\
\text { age }\end{array}$ & $\begin{array}{l}\mathrm{CK}, \mathrm{IU} / \mathrm{l}, \\
\text { range }\end{array}$ & $\begin{array}{l}\text { ECG and } \\
\text { cardiac US }\end{array}$ & $\begin{array}{l}\text { Spiro- } \\
\text { ergo- } \\
\text { metry }\end{array}$ & Clinical phenotype & $\begin{array}{l}\text { MRI } \\
\text { thighs }\end{array}$ & $\begin{array}{l}\text { MRI } \\
\text { legs }\end{array}$ & Biopsy & EMG & $\begin{array}{l}\text { ANO5 } \\
\text { genotype }\end{array}$ \\
\hline $11(\mathrm{~J})$ & $\mathrm{M}$ & 37 & 56 & $730-3,500$ & $\begin{array}{l}\text { ECG } \\
\text { normal, US } \\
\text { ND }\end{array}$ & - & $\begin{array}{l}\text { LL predominant } \\
\text { weakness and cramps, } \\
\text { cerebral white matter } \\
\text { hyperintensities }\end{array}$ & 0 & 1 & $\begin{array}{l}\text { Mild type } 2 \text { fiber } \\
\text { atrophy }\end{array}$ & $\begin{array}{l}\text { Myopathic } \\
\text { and } \\
\text { neurogenic } \\
\text { features }\end{array}$ & $\begin{array}{l}\text { p.R758C } \\
+ \text { p.M70R }\end{array}$ \\
\hline $12(\mathrm{~J})$ & $\mathrm{F}$ & 41 & $\begin{array}{l}\text { Decease } \\
\text { d age } 52\end{array}$ & $\begin{array}{l}271- \\
11,743\end{array}$ & Normal & + & $\begin{array}{l}\text { Left predominant LL } \\
\text { weakness, myalgia, } \\
\text { recurrent } \\
\text { myoglobinuria, central } \\
\text { pontine hyperintensity }\end{array}$ & 0 & 0 & Myopathic changes & $\begin{array}{l}\text { Myopathic } \\
\text { and } \\
\text { neurogenic } \\
\text { features }\end{array}$ & $\begin{array}{l}\text { p.R758C } \\
+ \\
\text { p.M470R }\end{array}$ \\
\hline $13(\mathrm{~K})$ & M & 20 & 56 & $\begin{array}{l}2,750- \\
12,290\end{array}$ & $\begin{array}{l}\text { ECG } \\
\text { normal, US } \\
\text { ND }\end{array}$ & + & $\begin{array}{l}\text { Asymptomatic, CK } \\
\text { elevation by chance }\end{array}$ & 4 & 5 & $\begin{array}{l}\text { Mild dystrophic } \\
\text { features }\end{array}$ & Myopathic & $\begin{array}{l}\text { p.R758C } \\
+ \\
\text { p.R758C }\end{array}$ \\
\hline $14(\mathrm{~K})$ & M & 25 & 49 & $\begin{array}{l}3,822- \\
10,471\end{array}$ & $\begin{array}{l}\text { ECG } \\
\text { normal, US } \\
\text { ND } \\
\end{array}$ & + & $\begin{array}{l}\text { LL muscle weakness, } \\
\text { myalgia }\end{array}$ & 7 & 5 & Dystrophic features & Myopathic & $\begin{array}{l}\text { p.R758C } \\
+ \\
\text { p.R758C }\end{array}$ \\
\hline
\end{tabular}

Table 2. Summary of clinical and genetic findings. MRI shows total scores of muscle involvement on T1-weighted imaging for the

thighs and the legs (muscles in the legs and the thighs divided into five groups and scored 0 to 3 such that a total score of 15 indicates

maximal involvement and 0 indicates no involvement). For patients who had two scans, the results from the latest scan are shown. CK

$=$ creatine kinase, $\mathrm{LL}=$ lower limbs, $\mathrm{ND}=$ not done, $\mathrm{UL}=$ upper limbs, $\mathrm{US}=$ ultrasound. 


\begin{tabular}{|llll|}
\hline & Muscle group & T1 & STIR \\
\hline \multirow{4}{*}{ Thighs } & Adductors & 1.7 & 0.5 \\
\cline { 2 - 4 } & Hamstrings & 1.5 & 1.0 \\
\cline { 2 - 4 } & Quadriceps & 0.7 & 0.7 \\
\cline { 2 - 4 } & Gracilis & 0.2 & 0.2 \\
\cline { 2 - 4 } & Sartorius & 0.1 & 0.2 \\
\hline \multirow{3}{*}{ Legs } & Gastrocnemius & 2.1 & 1.1 \\
\cline { 2 - 4 } & Soleus & 0.7 & 1.1 \\
\cline { 2 - 4 } & Anterior compartment & 0.2 & 0.1 \\
\cline { 2 - 4 } & Peroneal compartment & 0 & 0 \\
& Deep posterior & \\
& & 0 & 0 \\
& compartment & & \\
\hline
\end{tabular}

Table 3. Muscle imaging. Muscle involvement on MRI imaging is scored 0 to 3 , where 0 indicates no involvement and 3 indicates maximal involvement. Average scores are shown for T1 and STIR images. 


\begin{tabular}{|c|c|c|c|}
\hline Parameter & $\begin{array}{l}\text { ANO5, } \\
N=12\end{array}$ & $\begin{array}{l}\text { Healthy } \\
\text { controls, } \\
N=24\end{array}$ & $P$-Value \\
\hline Maximum heart rate & $172(12.5)$ & $162.3(30.3)$ & NS \\
\hline Maximum heart rate $\%$ & $89.1(15.8)$ & $93.1(8.7)$ & NS \\
\hline AT\% of expected maximal $\mathrm{V}^{\prime} \mathrm{O}_{2}$ & $51.6(16.8)$ & $66.7(20.2)$ & NS \\
\hline $\mathrm{Wmax} / 3 \min (\mathrm{W})$ & $108.92(46.9)$ & $\begin{array}{l}208.54 \\
(74.74)\end{array}$ & 0.00 \\
\hline $\mathrm{Wmax} / 3 \mathrm{~min} \%$ of predicted & $67.8(28.1)$ & $114.36(26.2)$ & $<0.001$ \\
\hline $\begin{array}{l}\mathrm{V}^{\prime} \mathrm{O}_{2} \max (\text { maximum oxygen } \\
\text { uptake) }(1 / \mathrm{min})\end{array}$ & $1.86(0.61)$ & $3.7(4.04)$ & NS \\
\hline $\mathrm{V}^{\prime} \mathrm{O}_{2} \max \%$ of predicted & $86.1(29.5)$ & $122.1(26.8)$ & 0.001 \\
\hline $\mathrm{V}^{\prime} \mathrm{O}_{2} \max (\mathrm{ml} / \mathrm{min} / \mathrm{kg})$ & $22.9(5.7)$ & $38.4(11.9)$ & 0.002 \\
\hline $\mathrm{V}^{\prime} \mathrm{O}_{2} \mathrm{max} / \mathrm{kg}$ of predicted $(\%)$ & $76.5(22.7)$ & $120.0(27.0)$ & 0.002 \\
\hline $\mathrm{V}^{\prime} \mathrm{O}_{2} / \mathrm{HR} \%$ of predicted $(\%)$ & $101.8(33.1)$ & $136.3(25.6)$ & 0.001 \\
\hline $\begin{array}{l}\text { Respiratory quotient } \\
\left(\mathrm{V}^{\prime} \mathrm{CO}_{2} \mathrm{max} / \mathrm{V}^{\prime} \mathrm{O}_{2} \mathrm{max}, \mathrm{RQ}\right)\end{array}$ & $1.22(0.08)$ & $1.13(0.64)$ & 0.001 \\
\hline $\mathrm{VEO}_{2} \%$ of predicted $(\%)$ & $136.7(16.6)$ & $110.8(15.5)$ & $<0.001$ \\
\hline $\mathrm{VECO}_{2} \%$ of predicted $(\%)$ & $124.1(14.3)$ & $109.7(14.0)$ & 0.002 \\
\hline $\begin{array}{l}\text { Fraction of end-tidal } \mathrm{CO}_{2} \\
\left(\mathrm{FetCO}_{2}\right)(\%)\end{array}$ & $4.65(0.48)$ & $5.3(0.51)$ & $<0.001$ \\
\hline $\mathrm{Wmax} / \mathrm{VO}_{2} \max (\%)$ & $16.3(4.8)$ & $20.8(1.8)$ & 0.004 \\
\hline Breathing frequency (1/min) & $37.92(10.7)$ & $37.45(8.9)$ & NS \\
\hline Tidal volume $\%$ or predicted $(\%)$ & $93.4(28.6)$ & $112.1(18.2)$ & NS \\
\hline $\begin{array}{l}\text { Subjective maximum strength } \\
\text { perceived }\end{array}$ & $18.8(0.87)$ & $18.39(0.90)$ & NS \\
\hline
\end{tabular}

Table 4. Spiroergometric data for patients with ANO5 and healthy controls. AT = anaerobic threshold, $\mathrm{Wmax} / 3 \mathrm{~min}=$ mean workload during the last $3 \mathrm{~min}$ of exercise, maximal $\mathrm{V}^{\prime} \mathrm{O}_{2} \max =$ maximal oxygen uptake, $\mathrm{VECO} 2$ = ventilatory equivalent for $\mathrm{CO} 2$ production, $\mathrm{VEO} 2$ = ventilatory equivalent for $\mathrm{O} 2$ uptake, $\mathrm{Wmax} / \mathrm{V}^{\prime} \mathrm{O}_{2} \max =$ mechanical efficiency. Comparisons were controlled for the maximal lactate levels and BMI. Level of significance after Bonferroni correction is $P<0.003$. 


\section{FIGURE LEGENDS}

Figure 1. Muscle imaging. Lower limb MRI from patient 9 shows the disease progression over 2 years. The first images for the thighs (A-B) are compared to later images (D-E), illustrating that the most prominent changes can be found in the progressive fatty infiltration symmetrically in the adductors, biceps femoris, quadriceps (vastus lateralis and intermedius, and rectus femoris), and left semimembranosus muscles. In the legs ( $\mathbf{C}$ and F), selective and progressive involvement of the medial head of the gastrocnemius muscle can be found, with more prominent changes visible on the left-hand side.

Figure 2. Results from exercise testing. Spiroergometric results showing the levels of ammonia and lactate in 12 patients and 24 healthy controls. Significantly lower lactate levels are visible in patients compared to controls $(P=0.049)$ at 2 and 4 min after exercise. No differences exist in the levels of ammonia between patients and controls. Mean and standard deviation, $* P<0.05$. 
Figure 1.
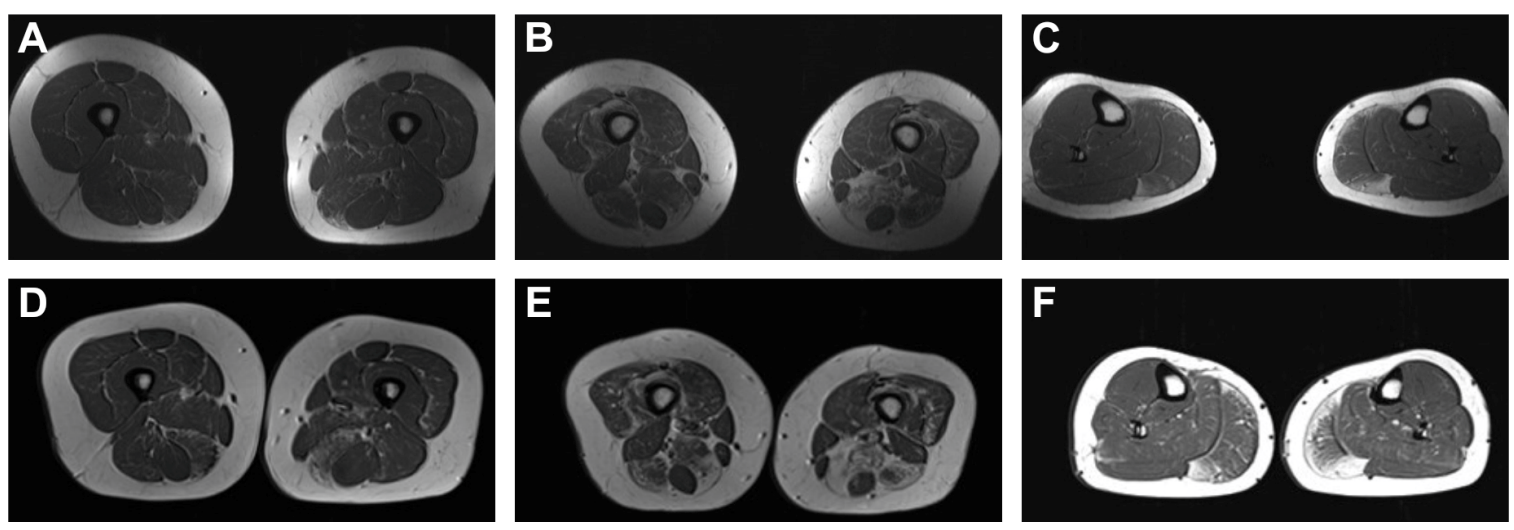
Figure 2.
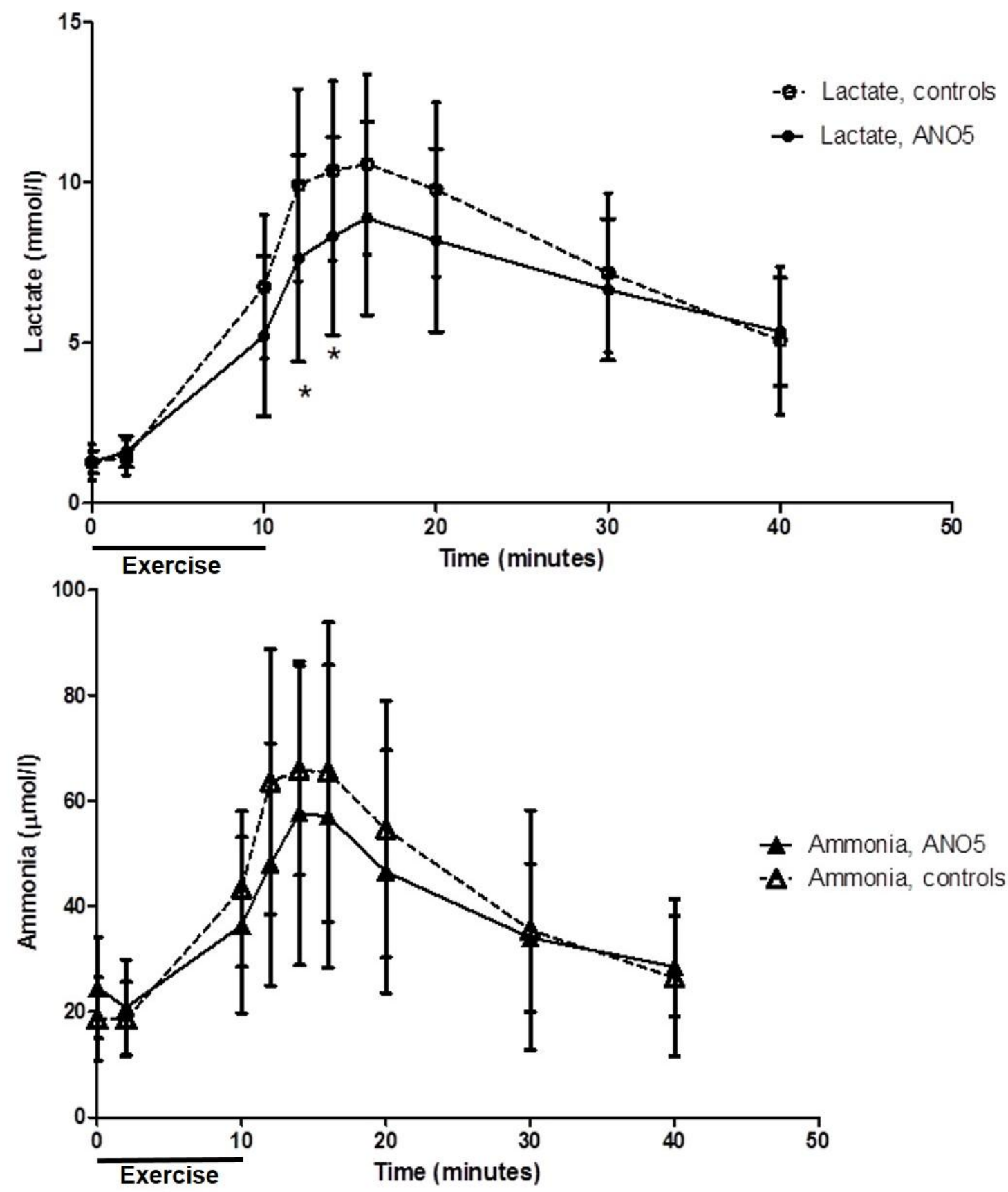


\section{REFERENCES}

[1] Mahjneh I, Jaiswal J, Lamminen A, Somer M, Marlow G, Kiuru-Enari S, Bashir R. A new distal myopathy with mutation in anoctamin 5. Neuromuscul Disord 2010; 20: 791795. doi 10.1016/j.nmd.2010.07.270.

[2] Bolduc V, Marlow G, Boycott KM, Saleki K, Inoue H, Kroon J, Itakura M, Robitaille Y, Parent L, Baas F, Mizuta K, Kamata N, Richard I, Linssen WH, Mahjneh I, de Visser M, Bashir R, Brais B. Recessive mutations in the putative calcium-activated chloride channel Anoctamin 5 cause proximal LGMD2L and distal MMD3 muscular dystrophies. Am J Hum Genet 2010; 86: 213-221. doi 10.1016/j.ajhg.2009.12.013.

[3] Penttila S, Palmio J, Suominen T, Raheem O, Evila A, Muelas Gomez N, Tasca G, Waddell LB, Clarke NF, Barboi A, Hackman P, Udd B. Eight new mutations and the expanding phenotype variability in muscular dystrophy caused by ANO5. Neurology 2012; 78: 897-903. doi 10.1212/WNL.0b013e31824c4682.

[4] Wahbi K, Behin A, Becane HM, Leturcq F, Cossee M, Laforet P, Stojkovic T, Carlier P, Toussaint M, Gaxotte V, Cluzel P, Eymard B, Duboc D. Dilated cardiomyopathy in patients with mutations in anoctamin 5. Int J Cardiol 2013; 168: 76-79. doi 10.1016/j.ijcard.2012.09.070.

[5] Witting N, Duno M, Petri H, Krag T, Bundgaard H, Kober L, Vissing J. Anoctamin 5 muscular dystrophy in Denmark: prevalence, genotypes, phenotypes, cardiac findings, and muscle protein expression. J Neurol 2013; 260: 2084-2093. doi 10.1007/s00415-0136934-y. 
[6] Sarkozy A, Deschauer M, Carlier RY, Schrank B, Seeger J, Walter MC, Schoser B, Reilich P, Leturq F, Radunovic A, Behin A, Laforet P, Eymard B, Schreiber H, Hicks D, Vaidya SS, Glaser D, Carlier PG, Bushby K, Lochmuller H, Straub V. Muscle MRI findings in limb girdle muscular dystrophy type 2L. Neuromuscul Disord 2012; 22 Suppl 2: S122-9. doi 10.1016/j.nmd.2012.05.012.

[7] Ten Dam L, van der Kooi AJ, Rovekamp F, Linssen WH, de Visser M. Comparing clinical data and muscle imaging of DYSF and ANO5 related muscular dystrophies. Neuromuscul Disord 2014; 24: 1097-1102. doi 10.1016/j.nmd.2014.07.004.

[8] Mahjneh I, Bashir R, Kiuru-Enari S, Linssen W, Lamminen A, Visser M. Selective pattern of muscle involvement seen in distal muscular dystrophy associated with anoctamin 5 mutations: a follow-up muscle MRI study. Neuromuscul Disord 2012; 22 Suppl 2: S130-6. doi 10.1016/j.nmd.2012.02.007.

[9] Vissing CR, Preisler N, Husu E, Prahm KP, Vissing J. Aerobic training in patients with anoctamin 5 myopathy and hyperckemia. Muscle Nerve 2014; 50: 119-123. doi 10.1002/mus.24112.

[10] Volpi L, Ricci G, Orsucci D, Alessi R, Bertolucci F, Piazza S, Simoncini C, Mancuso M, Siciliano G. Metabolic myopathies: functional evaluation by different exercise testing approaches. Musculoskelet Surg 2011; 95: 59-67. doi 10.1007/s12306011-0096-9. 
[11] Adzhubei IA, Schmidt S, Peshkin L, Ramensky VE, Gerasimova A, Bork P, Kondrashov AS, Sunyaev SR. A method and server for predicting damaging missense mutations. Nat Methods 2010; 7: 248-249. doi 10.1038/nmeth0410-248.

[12] Schwarz JM, Cooper DN, Schuelke M, Seelow D. MutationTaster2: mutation prediction for the deep-sequencing age. Nat Methods 2014; 11: 361-362. doi 10.1038/nmeth.2890.

[13] Mustelin L, Pietilainen KH, Rissanen A, Sovijarvi AR, Piirila P, Naukkarinen J, Peltonen L, Kaprio J, Yki-Jarvinen H. Acquired obesity and poor physical fitness impair expression of genes of mitochondrial oxidative phosphorylation in monozygotic twins discordant for obesity. Am J Physiol Endocrinol Metab 2008; 295: E148-54. doi 10.1152/ajpendo.00580.2007

[14] Hicks D, Sarkozy A, Muelas N, Koehler K, Huebner A, Hudson G, Chinnery PF, Barresi R, Eagle M, Polvikoski T, Bailey G, Miller J, Radunovic A, Hughes PJ, Roberts R, Krause S, Walter MC, Laval SH, Straub V, Lochmuller H, Bushby K. A founder mutation in Anoctamin 5 is a major cause of limb-girdle muscular dystrophy. Brain 2011; 134: 171-182. doi 10.1093/brain/awq294.

[15] van der Kooi AJ, Ten Dam L, Frankhuizen WS, Straathof CS, van Doorn PA, de Visser M, Ginjaar IB. ANO5 mutations in the Dutch limb girdle muscular dystrophy population. Neuromuscul Disord 2013; 23: 456-460. doi 10.1016/j.nmd.2013.03.012.

[16] Stehlikova K, Skalova D, Zidkova J, Mrazova L, Vondracek P, Mazanec R, Vohanka S, Haberlova J, Hermanova M, Zamecnik J, Soucek O, Oslejskova H, 
Dvorackova N, Solarova P, Fajkusova L. Autosomal recessive limb-girdle muscular dystrophies in the Czech Republic. BMC Neurol 2014; 14: 154-014-0154-7. doi 10.1186/s12883-014-0154-7.

[17] Savarese M, Di Fruscio G, Tasca G, Ruggiero L, Janssens S, De Bleecker J, Delpech M, Musumeci O, Toscano A, Angelini C, Sacconi S, Santoro L, Ricci E, Claes K, Politano L, Nigro V. Next generation sequencing on patients with LGMD and nonspecific myopathies: Findings associated with ANO5 mutations. Neuromuscul Disord 2015; 25: 533-541. doi 10.1016/j.nmd.2015.03.011.

[18] Bohlega S, Monies DM, Abulaban AA, Murad HN, Alhindi HN, Meyer BF. Clinical and genetic features of anoctaminopathy in Saudi Arabia. Neurosciences (Riyadh) 2015; 20: 173-177. doi 10.17712/nsj.2015.2.20140547.

[19] Magri F, Del Bo R, D'Angelo MG, Sciacco M, Gandossini S, Govoni A, Napoli L, Ciscato P, Fortunato F, Brighina E, Bonato S, Bordoni A, Lucchini V, Corti S, Moggio M, Bresolin N, Comi GP. Frequency and characterisation of anoctamin 5 mutations in a cohort of Italian limb-girdle muscular dystrophy patients. Neuromuscul Disord 2012; 22: 934-943. doi 10.1016/j.nmd.2012.05.001.

[20] Liewluck T, Winder TL, Dimberg EL, Crum BA, Heppelmann CJ, Wang Y, Bergen HR,3rd, Milone M. ANO5-muscular dystrophy: clinical, pathological and molecular findings. Eur J Neurol 2013; 20: 1383-1389. doi 10.1111/ene.12191. 
[21] Jarry J, Rioux MF, Bolduc V, Robitaille Y, Khoury V, Thiffault I, Tetreault M, Loisel L, Bouchard JP, Brais B. A novel autosomal recessive limb-girdle muscular dystrophy with quadriceps atrophy maps to 11 p13-p12. Brain 2007; 130: 368-380.

[22] Sarkozy A, Hicks D, Hudson J, Laval SH, Barresi R, Hilton-Jones D, Deschauer M, Harris E, Rufibach L, Hwang E, Bashir R, Walter MC, Krause S, van den Bergh P, Illa I, Penisson-Besnier I, De Waele L, Turnbull D, Guglieri M, Schrank B, Schoser B, Seeger J, Schreiber H, Glaser D, Eagle M, Bailey G, Walters R, Longman C, Norwood F, Winer J, Muntoni F, Hanna M, Roberts M, Bindoff LA, Brierley C, Cooper RG, Cottrell DA, Davies NP, Gibson A, Gorman GS, Hammans S, Jackson AP, Khan A, Lane R, McConville J, McEntagart M, Al-Memar A, Nixon J, Panicker J, Parton M, Petty R, Price CJ, Rakowicz W, Ray P, Schapira AH, Swingler R, Turner C, Wagner KR, Maddison P, Shaw PJ, Straub V, Bushby K, Lochmuller H. ANO5 gene analysis in a large cohort of patients with anoctaminopathy: confirmation of male prevalence and high occurrence of the common exon 5 gene mutation. Hum Mutat 2013; 34: 1111-1118. doi 10.1002/humu.22342.

[23] Myers J, Froelicher VF. Hemodynamic determinants of exercise capacity in chronic heart failure. Ann Intern Med 1991; 115: 377-386.

[24] Wasserman K. Diagnosing cardiovascular and lung pathophysiology from exercise gas exchange. Chest 1997; 112: 1091-1101. 